\title{
NationWIde OUtBREAK OF Salmonella ENTERICA SEROTYPE KEDOUGOU INFECTION IN INFANTS LINKED TO INFANT FORMULA MILK, SPAIN, 2008
}

\author{
Pilar Soler (psoler@isciii.es) ${ }^{1}$, S Herrera ${ }^{2}$, J Rodriguez ${ }^{3}$, J Cascante $^{3}$, R Cabral ${ }^{3}$, A Echeita-Sarriondia ${ }^{2}$, S Mateo ${ }^{1}$, on behalf \\ of the National Surveillance Network of Spain
}

1. National Centre of Epidemiology, Instituto de Salud Carlos III, Madrid, Spain

2. National Centre of Microbiology, Instituto de Salud Carlos III, Madrid, Spain

3. Spanish Programme for Intervention Epidemiology Training (PEAC)

On 5 August 2008, the National Reference Laboratory of Salmonella (NRLS) noted an increase in the number of isolates of Salmonella enterica serotype Kedougou. As of 22 August, 29 isolates have been reported during 2008 , which is ten times more than the average number of isolates identified by the NRLS during 2002-2007. All isolates have a typical, indistinguishable Pulse Field pattern (SALKEDXB-1, Spanish code) and are fully sensitive to the standard suite of antimicrobials.

Of the 29 patients with $S$. Kedougou, 12 were male. Twenty three patients were younger than one year while the remaining six were aged between seven and 76 years. From the available information we know that one of the adult patients is the father of one infant infected with $S$. Kedougou.

In the context of this outbreak we defined a case as an infant younger than one year old with clinical symptoms compatible with a salmonella infection and an isolate of $S$. Kedougou from stools, blood or urine, since 1 January 2008. As of 22 August, 23 cases fulfilling the case-definition were identified with the onset of symptoms between 4 February and 28 July 2008 (Figure).

To date, 19 of these cases have been investigated. The children live in seven different regions throughout Spain. The parents of all 19 infants reported feeding them with powdered formula milk of the same brand in the week before onset of symptoms. The main symptoms were diarrhoea (100\%), fever (32\%), nausea (21\%) and vomiting (21\%). Six cases were hospitalised.

F I G U R E

Cases of Salmonella Kedougou infection in infants by week of onset of symptoms, Spain, $2008(n=23)$

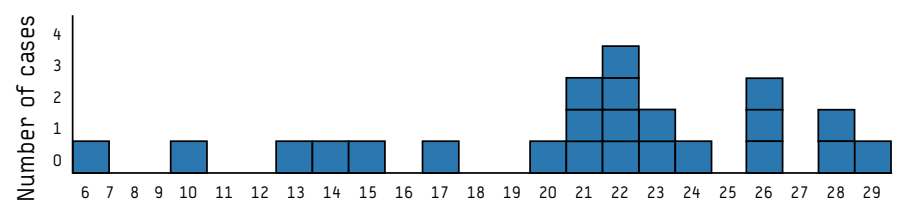

Week of onset, 2008
A matched case control study was carried out by the Surveillance National Network, and included 10 cases and 36 controls. The study showed that illness was significantly associated with the consumption of a particular brand of formula milk for infants (chisquare=26.03; $d f=1 ; P<0,0001$ ).

These preliminary results strongly suggest that the infant formula milk was the source of the outbreak. On 26 August, based on the preliminary results of the epidemiological investigation, and as a precautionary measure, the Spanish food safety authorities recalled five batches of formula milk produced under the incriminated brand. These batches had only been distributed in Spain.

An urgent inquiry was posted trough the European Centre for Disease Prevention and Control (ECDC) to the European Network of Food and Waterborne Diseases (former ENTER-net) on 7 August. From the responses received until 22 August it seems that no country had detected an increase in $S$. Kedougou isolates. Although the infant formula milk has only been distributed in Spain, an alert to the Rapid Alert System for Food and Feed (RASFF) (number 2008.1034) was sent on 27 August by the Spanish Food Safety Agency.

S. Kedougou is one of approximately 2000 Salmonella serotypes that can cause illness in humans but it is rarely reported in Spain. On average, three isolates per year were identified by the NRLS between 2002 and 2007. We have found only two outbreaks of $S$. Kedougou described in literature, one associated with salami [1], the other with jam and turkey meat [2]. We are not aware of any outbreak of $S$. Kedougou caused by the consumption of infant formula milk. However, other serotypes of Salmonella have been associated with outbreaks linked to infant formula milk [3-12], one of them in our country $[3,4]$.

\section{References}

1. Emberland KE, Nygard K, Heier BT, Aavitsland P, Lassen J, Stavnes TL, Gondrosen B. Outbreak of Salmonella Kedougou in Norway associated with salami, AprilJune 2006. Euro Surveill. 2006;11(27):pii=2995. Available from: http://www. eurosurveillance.org/ViewArticle.aspx?ArticleId=2995. 
2. Salmonella kedougou and cooked meats. Commun Dis Rep CDR Wkly 1992; 2(35):159.

3. Brote por Salmonella virchow fermentadora de lactosa. Boletín Epidemiológico Semanal 1994;2:209-212.

4. Usera MA, Rodriguez A, Echeita A, Cano R. Multiple analysis of a foodborne outbreak caused by infant formula contaminated by an atypical Salmonella virchow strain. Eur J Clin Microbiol Infect Dis 1998;17(8):551-555.

5. International investigation: Belgium United Kingdom France and the Salm-Net network. Preliminary report of an international outbreak of Salmonella anatum infection linked to an infant formula milk. Euro Surveill. 1997;2(3):pii=190. Available from: http://www.eurosurveillance.org/ViewArticle. aspx?ArticleId $=190$.

6. Djuretic T. Salmonella java PT Worksop in young children associated with fortified milk. Euro Surveill. 1997;1(14):pij=1068. Available from: http://www. eurosurveillance.org/ViewArticle.aspx?ArticleId $=1068$

7. Cahill SM, Wachsmuth IK, Costarrica Mde L, Ben Embarek PK. Powdered infant formula as a source of Salmonella infection in infants. Clin Infect Dis. 2008:46(2):268-73.

8. Rowe B, Begg NT, Hutchinson DN, Dawkins HC, Gilbert RJ, Jacob M, et al. Salmonella ealing infections associated with consumption of infant dried milk. Lancet. 1987;2(8564):900-3.

9. Centers for Disease Control and Prevention. Salmonella serotype Tennessee in powdered milk products and infant formula-Canada and the United States, 1993. MMWR Morb Mortal Wkly Rep 1993;42:516-7.

10. Threlfall EJ, Ward LR, Hampton MD, Ridley AM, Rowe B, Roberts D, et al. Molecular fingerprinting defines a strain of Salmonella enterica serotype Anatum responsible for an international outbreak associated with formuladried milk. Epidemiol Infect. 1998;121(2):289-93.

11. Park JK, Seok WS, Choi BJ, Kim HM, Lim BK, Yoon SS, et al. Salmonella enterica serovar London infections associated with consumption of infant formula. Yonsei Med J. 2004;45(1):43-8.

12. Brouard C, Espié E, Weill FX, Kérouanton A, Brisabois A, Forgue AM, et al. Two consecutive large outbreaks of Salmonella enterica serotype Agona infections in infants linked to the consumption of powdered infant formula. Pediatr Infect Dis J. 2007;26(2):148-52.

This article was published on 28 August 2008.

Citation style for this article: Soler P, Herrera S, Rodríguez J, Cascante J, Cabral R, Echeita-Sarriondia A, Mateo $S$, on behalf of the National Surveillance Network of Spain. Nationwide outbreak of Salmonella enterica serotype Kedougou infection in infants linked to infant formula milk, Spain, 2008. Euro Surveill. 2008;13(35):pij=18963. Available online: $h t t p: / / w w w . e u r o s u r v e i l l a n c e . o r g / V i e w A r t i c l e . a s p x ? A r t i c l e I d=18963$ 